\title{
Preliminary investigations of organic pollution in water environment of some urban lakes in Hanoi city, Vietnam
}

\author{
Bước đầu đánh giá ô nhiễm hữu co trong môi trương nước của một số hồ Hà \\ Nội, Việt Nam \\ Research article
}

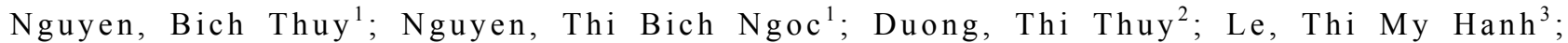
Pham, Quoc Long ${ }^{1}$; Le, Duc Nghia ${ }^{1}$; Le, Thi Phuong Quynh ${ }^{1}$

${ }^{1}$ Institute of Natural Product Chemistry, Vietnam Academy of Science and Technology (VAST), 18 Hoang Quoc Viet, Hanoi, Vietnam; ${ }^{2}$ Institute of Environmental Technology, VAST, 18 Hoang Quoc Viet, Hanoi, Vietnam; ${ }^{3}$ Institute of Tropical Technology, VAST, 18 Hoang Quoc Viet, Hanoi, Vietnam

\begin{abstract}
Lakes in Hanoi play an important role in local human life. However, along with the economic and social development, some urban lakes have been polluted, especially organic pollution. This paper presents the monthly survey results for organic pollution assessment of ten selected lakes in Ha Noi city: the Ho Tay, Truc Bach, Thien Quang, Ba Mau, Bay Mau, Hoan Kiem, Ngoc Khanh, Giang Vo, Thanh Cong and Thu Le lakes during the period from March 2014 to February 2015. The survey results showed that the Ba Mau lake was organic polluted at level IV whereas other lakes were contaminated by organic matters at level III. Organic pollution may come from both autochthonous and allochthonous sources. Compared with the results of previous studies, the water quality of 10 lakes in the period from March 2014 to February 2015 has been improved thank for the recent application of some positive solutions for lake environmental protection.

Hệ thống hồ ở Hà Nội đóng vai trò quan trọng trong đời sống của người dân. Tuy nhiên, cùng với sự phát triển kinh tế xã hội, nhiều hồ trong nọi đô đã và đang bi ô nhiếm, đặc biệt là ô nhiếm hũu co: Bài báo này trình bày kết quả khảo sát ô nhiếm hũu co tại 10 hồ trong thành phố Hà Nộ: hồ Tây, Trúc Bạch, Thiền Quang, Ba Mẫu, Bảy Mẫu, Hoàn Kiếm, Ngọc Khánh, Giảng Võ, Thành Công và Thủ Lệ trong thời gian tù tháng 3 năm 2014 đến tháng 2 năm 2015. Kết quả khảo sát cho thấy hồ Ba Mẫu bi ô nhiễm hưu co ở mức IV, các hồ còn lại bi ô nhiễm hữu co ơ mức III. Ô nhiễm hữu co tại các hồ có thể do cả hai nguồn cung cấp chất hữu co, ngoại lai và nội sinh. So với kêt quả quan trắc trước đây, chất lương nước 10 hồ Hà Nội đã được cải thiện do gần đây đã áp dụng một số biện pháp bảo vệ môi trường cho các hồ.
\end{abstract}

Keywords: organic carbon, water pollution, urban lake, Hanoi 


\section{Introduction}

There are about 120 lakes and ponds located in Hanoi city, of which 17 lakes situated in the inner city. These lakes play an important role for local human lives: harmonize climate, regulate stormwater/rainfall, provide place for human entertainment, and unfortunately are also considered as a container for domestic wastewater for Hanoi.

Previous studies indicated that the water of most lakes in Hanoi is polluted and of which, some lakes (Hoan Kiem, Giang Vo, Thanh Cong, Ngoc Khanh etc.) were seriously polluted, e.g. very high values of BOD, COD were found (Le, 1999). As other big cities in developing countries, Hanoi faces problem of managing the domestic and industrial wastewater. The untreated or partially treated domestic and industrial wastewater which was discharged directly or indirectly to the lakes through the channels in the city has caused lake pollution. Recently, some positive solutions for lake protection such as lake embankment, preventing untreated wastewater to the lake have been taken. The application of these solutions may give an amelioration of lake water quality. In this paper, we aim to: i) investigate the present water quality of the 10 lakes in Hanoi city from March 2014 to February 2015, after application of these above positive solutions; ii) classify the organic pollution level of these lakes.

\section{Methodology}

\subsection{Study site}

Ten lakes in the inner Hanoi city were selected for observation including Ho Tay (HT), Truc Bach (TB), Thien Quang (TQ), Ba Mau (BaM), Bay Mau (ByM), Hoan Kiem (HK), Ngoc Khanh (NK), Giang Vo (GV), Thanh Cong (TC) and Thu Le (TL). Some characteristics of these lakes are presented in Table 1.

\begin{tabular}{lccc}
$\begin{array}{l}\text { Table 1. Some characteristics of } 10 \text { lakes observed } \\
\text { Lake name }\end{array}$ & $\begin{array}{c}\text { Code } \\
\text { Water surface } \\
\text { Depth }\end{array}$ & $\begin{array}{c}\text { Dea } \\
\text { (m) }\end{array}$ \\
\hline Ho Tay & HT & 446 & $2.0-4.0$ \\
Truc Bach & TB & 22 & $1.5-2.0$ \\
Bay Mau & ByM & 21.3 & $2.0-2.5$ \\
Hoan Kiem & HK & 12 & $1.5-2.0$ \\
Thu Le & TL & 9.9 & $2.0-3.0$ \\
Thanh Cong & TC & 6.5 & $3.0-4.0$ \\
Giang Vo & GV & 6 & $2.5-3.0$ \\
Thien Quang & TQ & 5.5 & $3.0-4.0$ \\
Ba Mau & BaM & 4.6 & $2.5-3.0$ \\
Ngoc Khanh & NK & 3.5 & 2.5
\end{tabular}

The climate in the study area, which is of tropical East Asia monsoon type, is characterized by two distinct seasons: rainy and dry season. The rainy season lasts from May to October and cumulates $85-90 \%$ of the total annual rainfall whereas the dry season covers the period from November to the next April.

\subsection{Method}

Monthly sampling campaigns were conducted at 10 lakes in Hanoi from March 2014 to February 2015. At each lake, surface water sample was monthly collected at three different points, then these three samples were well mixed together to give one sample for laboratory analysis.

Water quality checker WQC-22A (TOA, Japan) was used in-situ to measure temperature $\left({ }^{0} \mathrm{C}\right), \mathrm{pH}$, conductivity $\left(\mu \mathrm{S} . \mathrm{cm}^{-1}\right)$, turbidity (NTU), and dissolved oxygen (DO, $\mathrm{mgL}^{-1}$ ). Water samples (after well mixing) were filtered immediately by a vacuum filtration through a precombusted glass fiber filterpaper (Whatman GF/F, Ø47mm). Filtrates for DOC analysis were acidified and stored at $4^{0} \mathrm{C}$. All filters and other filtrates were kept in a freezer $(<$ $-20{ }^{0} \mathrm{C}$ ) after filtration until laboratory analysis.

Suspended solids were quantitatively determined on preweighed filterpaper. POC was determined semiquantitatively by filtration of $100 \mathrm{ml}$ water samples on Whatman GF/F filters and then filters were weighed before and after calcination at $550{ }^{\circ} \mathrm{C}$ for 4 hours. DOC concentrations were determined using a TOC- $\mathrm{V}_{\mathrm{E}}$ (Shimadzu, Japan). Nutrients (N, P, Si) and chlorophyll a were spectrophotometrically measured with an UV-VIS V-630 (JASCO, Japan) by different methods described in Le et al. (2005).

\subsection{Classification of organic pollution level}

To assess organic pollution level of 10 lakes in Hanoi, the method proposed by (Hawke, 1962) was applied in this study. Five organic pollution levels (level V is heavily polluted) for surface water quality were given based on concentrations of five variables $\mathrm{pH}, \mathrm{DO}, \mathrm{BOD}, \mathrm{NH}_{3}$, COD and SS (Tabel 2).

Table 2. Classification of organic pollution level for surface water (Hawke, 1962)

\begin{tabular}{lccccc}
$\begin{array}{l}\text { Levels } / \\
\text { Var. }\end{array}$ & $\begin{array}{c}\text { Level } \\
\text { I }\end{array}$ & $\begin{array}{c}\text { Level } \\
\text { II }\end{array}$ & $\begin{array}{c}\text { Level } \\
\text { III }\end{array}$ & $\begin{array}{c}\text { Level } \\
\text { IV }\end{array}$ & $\begin{array}{c}\text { Level } \\
\text { V }\end{array}$ \\
\hline $\mathbf{p H}$ & $6.5-8.0$ & $6.0-8.4$ & $5.0-9.0$ & $3.9-10.1$ & $<3.9 ;>10.1$ \\
$\begin{array}{l}\mathbf{D O} \\
\left.\mathbf{m g L}^{-\mathbf{1}}\right)\end{array}$ & 7.8 & 6.2 & 4.6 & 1.8 & $<1.8$ \\
$\begin{array}{l}\mathbf{B O D}_{\mathbf{5}} \\
\left.\mathbf{( m g L}^{-1}\right)\end{array}$ & 1.5 & 3.0 & 6.0 & 12.0 & $>12.0$ \\
$\begin{array}{l}\mathbf{N H}_{\mathbf{3}} \\
\left.\mathbf{( m g L}^{-1}\right)\end{array}$ & 0.1 & 0.3 & 0.9 & 2.7 & $>2.7$ \\
$\begin{array}{l}\mathbf{C O D} \\
\left.\mathbf{m g L}^{-1}\right)\end{array}$ & 10 & 20 & 40 & 80 & $>80$ \\
$\mathbf{S S}^{\mathbf{m}}$ & 20 & 40 & 100 & 278 & $>278$
\end{tabular}

In which: level I: Good; level II: Acceptable; level IIISlight pollution; level IV - Pollution; level V - Heavy pollution.

\section{Results and discussion}

\subsection{Physico-chemical variables}

$\boldsymbol{p H}$ : Most of the lakes are in naturally slight alkaline conditions with annual average $\mathrm{pH}$ value around 8 , except for 
the HK lake where $\mathrm{pH}$ values exceed the value of the Vietnam National technical regulation on surface water quality QCVN 08:2015/BTNMT column A2.

DO: DO concentrations were in a high range from 2.5 to $7.0 \mathrm{mgL}^{-1}$ (Tab. 3). The annual average values of the DO concentrations varied from $3.5 \mathrm{mgL}^{-1}$ ( $\mathrm{GV}$ lake) to 5.0 $\mathrm{mgL}^{-1}$ (HK lake). Almost annual mean values of DO of 10 lakes were lower or equal than the permitted value QCVN 08:2015/BTNMT col. A2 (> $\left.5 \mathrm{mgL}^{-1}\right)$ (Table 3$)$.

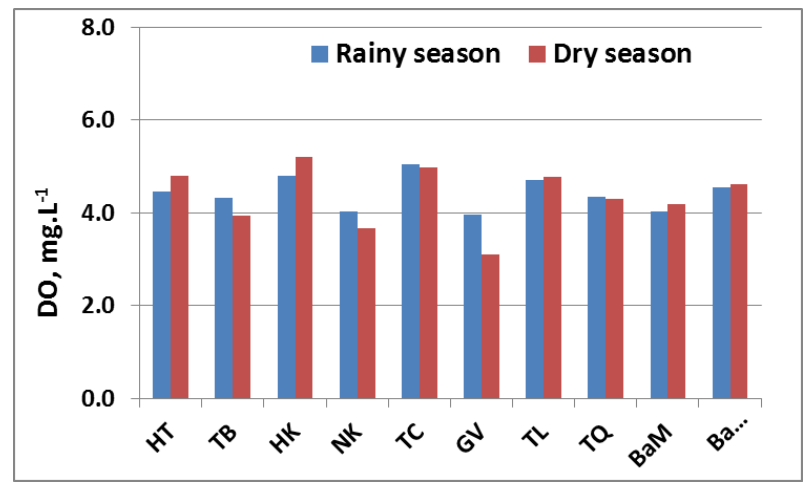

Figure 1. Average DO values in rainy and dry season of 10 lakes observed

The DO values remained almost low during all sampling campaigns (in day) and insignificantly changed in seasonal variation (Tab. 3, Fig. 1). As known, DO concentration depends on lake surface agitation, temperature, respiration rate of living organisms and decomposition rate of organic matters (Mathur et al., 2008). Low DO values are related to organic pollution and eutrophication as some lakes in the world: Dal lake $\left(3.0-8.2 \mathrm{mgL}^{-1}\right)$ (Mushatq et al., 2013); Manchhar lake (3.2 - $4.2 \mathrm{mgL}^{-1}$ ) (Channar et al., 2014).

Suspended solids (SS): Most toxic heavy metals, organic pollutants, pathogens, nutrients such as phosphorus and appreciable amount of biodegradable organic materials are associated to SS (Meybeck et al, 1989). The annual average values of SS concentrations of 10 lakes were from $11 \mathrm{mgL}^{-1}$ (TL lake) to $61 \mathrm{mgL}^{-1}$ (BaM lake). The high SS concentrations may relate to organic pollution because they contain particulate organic carbon (high SS concentrations related with high POC concentrations in lakes observed) (Tabel 3).

$\mathrm{NH}_{4}^{+}: \mathrm{NH}_{4}^{+}$concentrations varied in a high range from 0.01 to $20.74 \mathrm{mgL}^{-1}$ (Tab. 3), where the highest values were about 100 times higher than the permitted value of QCVN 08:2015/BTNMT column A2 $\left(\mathrm{NH}_{4}^{+}<0.3 \mathrm{mgL}^{-1}\right)$. The higher values in the dry season (winter and spring) than wet season (summer and autumn) were observed for most lakes, except the TC lake (Fig. 2). Afiq et al. (2012) indicated that $\mathrm{NH}_{4}{ }^{+}$probably enters into the lake system at higher concentrations in summer, but is rapidly assimilated by microorganisms and plants to forming organic nitrogen; in the winter, when metabolic processes are slower due to the low development of the plant life and the accumulation of degradation products, $\mathrm{NH}_{4}^{+}$concentrations are considerably higher.

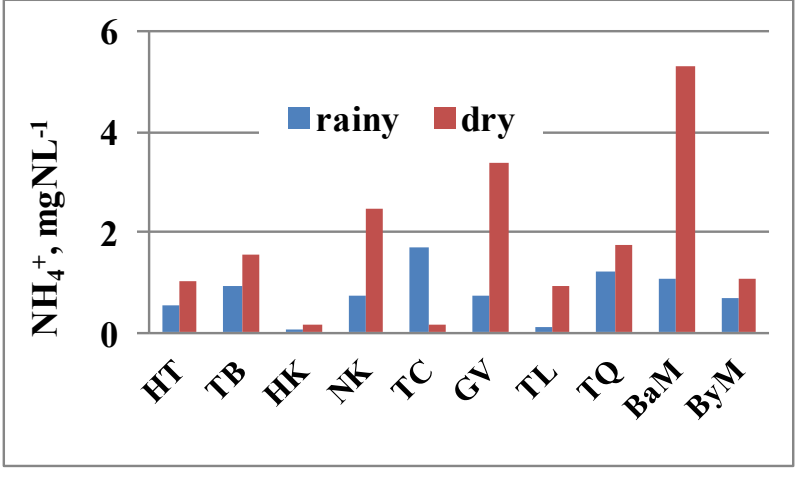

Figure 2. Average $\mathrm{NH}_{4}{ }^{+}$values in rainy and dry season of 10 lakes in Hanoi

Chlorophyll a (Chl-a): Chl-a concentrations fluctuated in a high range from 0.1 to $73.3 \mu \mathrm{gL}^{-1}$ (Tab. 3), where the highest value was obtained at the GV lake. The higher values in dry season than in the wet season (in summer) was observed (Tab. 3 and Fig. 3a). The pics of Chl-a in almost lakes appeared along with the highest nutrient concentrations, especially with phosphorus. This would suggest that algal growth in these lakes was more limited by phosphorus than by available light. Very high Chl-a in these lakes also suggested that the growth, death, and degradation of phytoplankton might be important sources of organic matters, as the case of Taihu lake (Yin et al., 2011).

\subsection{Organic carbon}

\section{Dissolved organic carbon (DOC)}

DOC concentrations varied largely from $2.5 \mathrm{mgL}^{-1}$ (at the HT lake) to $28.4 \mathrm{mgL}^{-1}$ (BaM lake). The mean annual DOC concentration was in the range from $5.1 \mathrm{mgL}^{-1}$ (TL and ByM lakes) to $10.5 \mathrm{mgL}^{-1}$ (HK lake). It seems that DOC values in dry seasons were higher than those in wet season, except the TB and BaM lakes (Fig. 3b). 


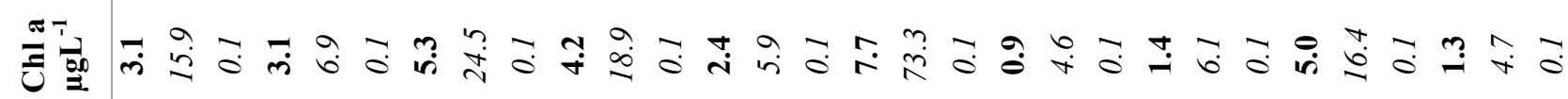

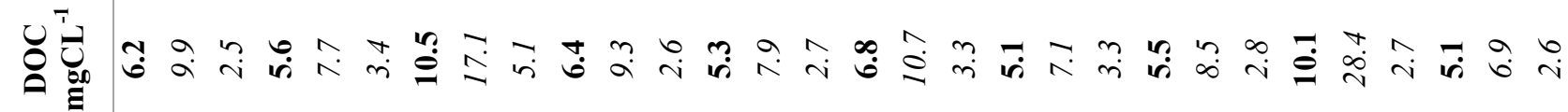

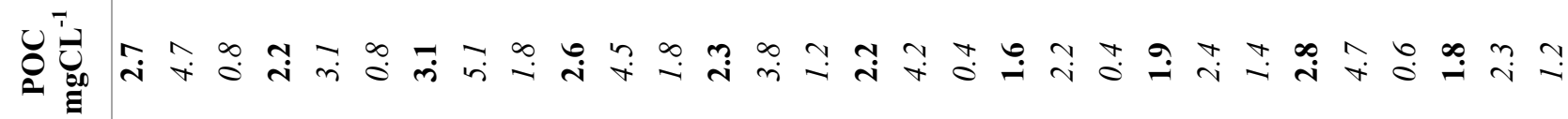

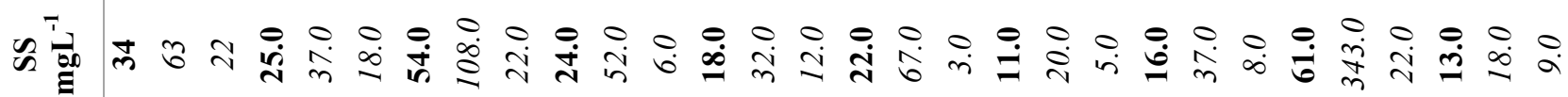

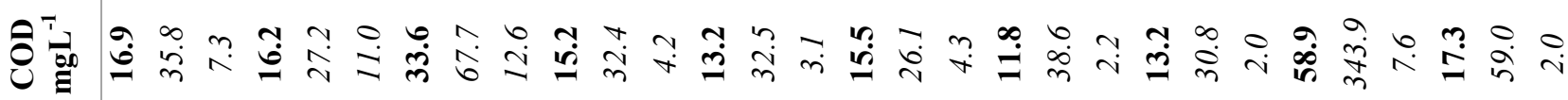

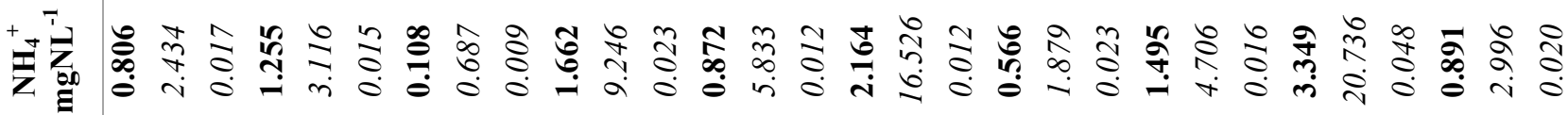

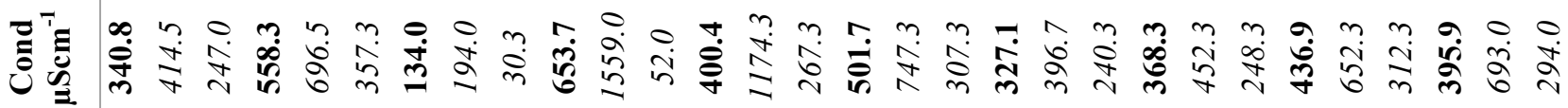

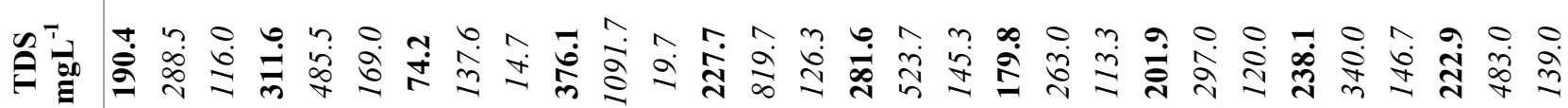

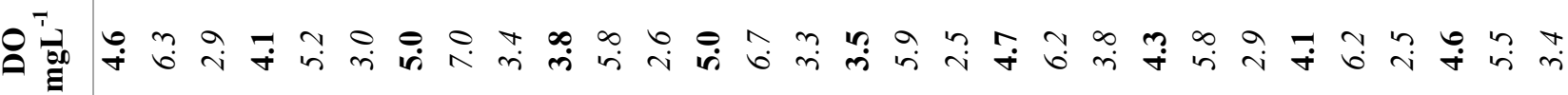

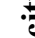

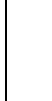

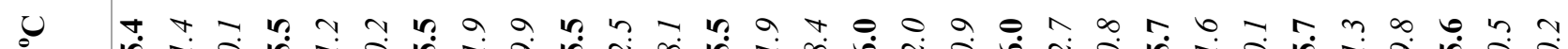

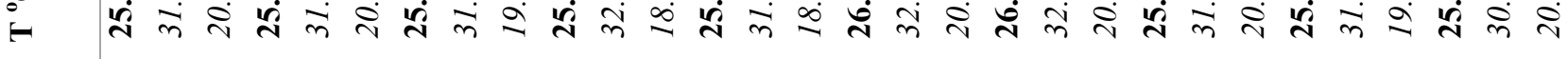

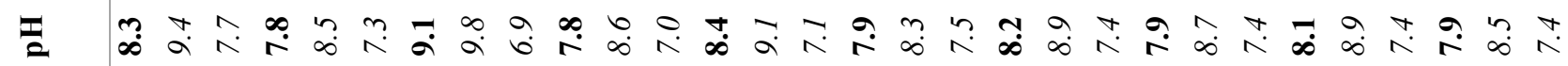
:

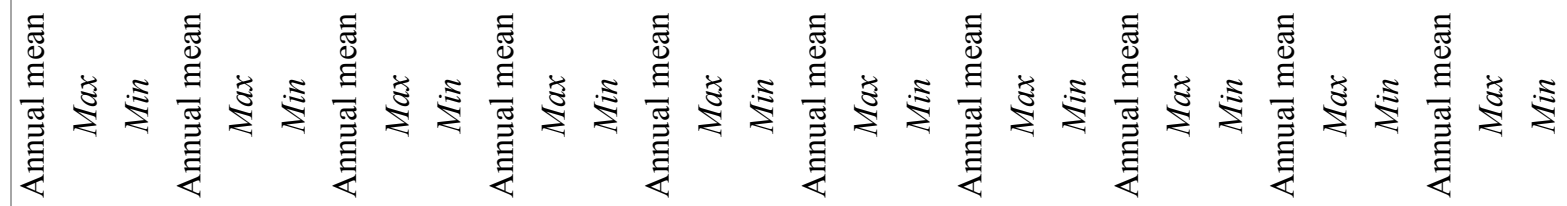

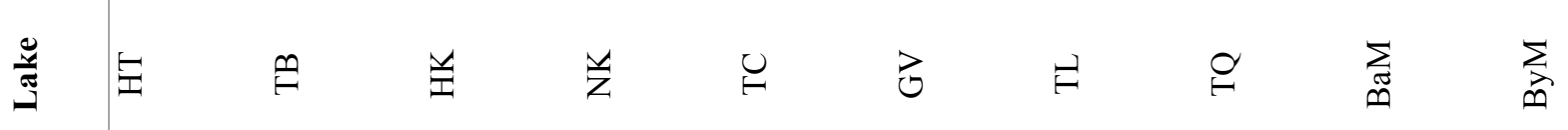




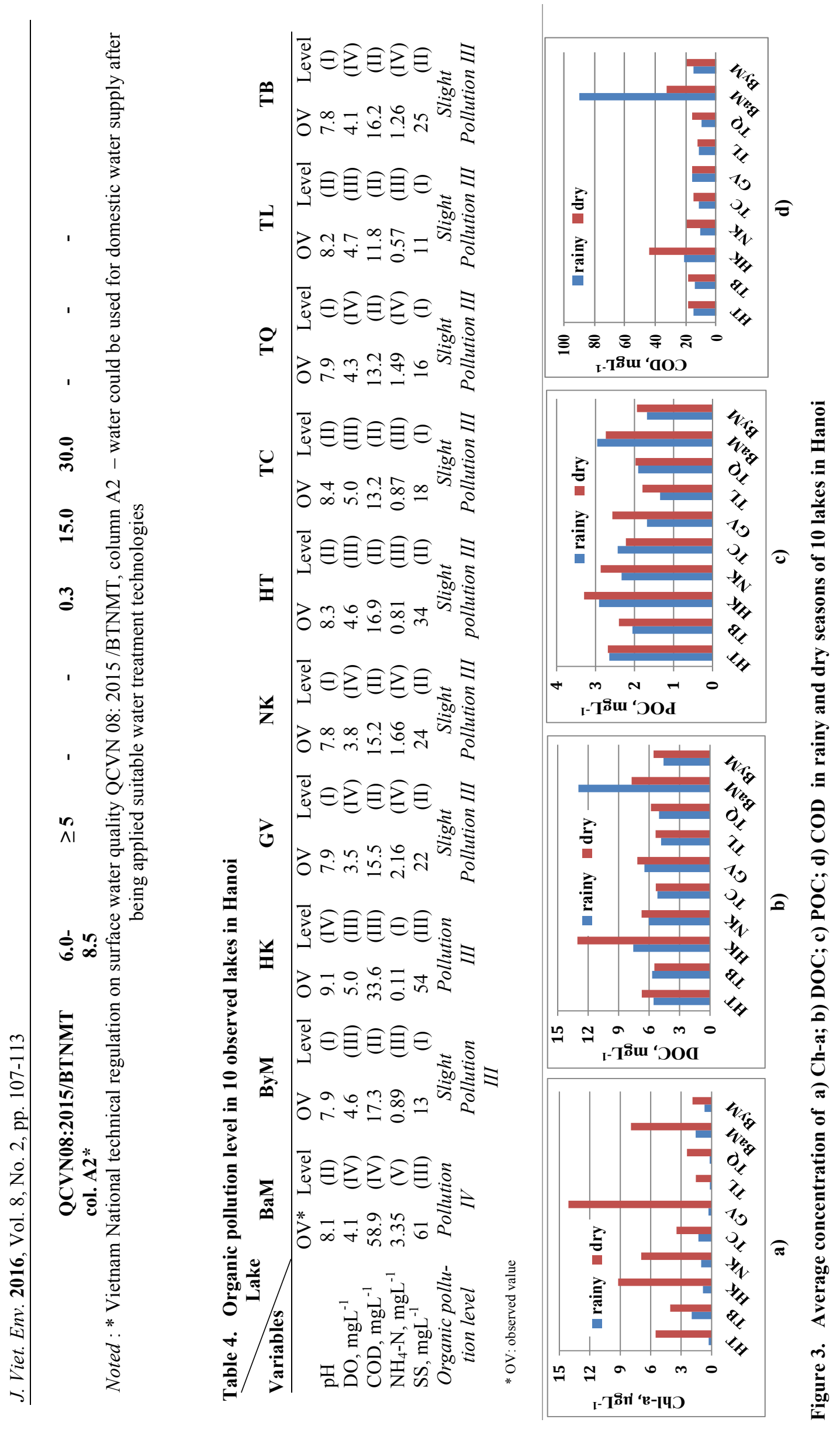


As known, organic carbon is found under dissolved or particulate form and is either autochthonous (produced in situ by algal biomass production and subsequently released by lysis or excretion) or allochthonous (brought to lakes from soil leaching, or domestic and industrial wastewater) (Kim et al., 2000). When brought by domestic effluent, a large part is biodegradable (>50\%), these inputs possibly lead to oxygen depletion due to respiration of heterotrophic bacteria. Similarly, when autochthonous primary production is high, due to ample nutrient concentrations, organic biomass of organisms can represent a large stock of biodegradable organic matter, heterotrophic degradation of which can also lead to oxygen depletion (Garnier et al., 2004). These two types of organic pollution, can lead to reduce oxygen level down to values inappropriate for aquatic life, fish in particular. This is true for the cases of 10 lakes in Hanoi that organic pollution may come from both autochthonous and allochthonous sources because very low DO values and very high pics of Chl-a values were observed during the study period.

\section{Particulate organic carbon (POC)}

POC concentrations in 10 lakes in Hanoi varied from 0.4 $\mathrm{mgL}^{-1}$ (GV and TL lakes) to $5.1 \mathrm{mgL}^{-1}$ (HK lake). The annual average values of POC concentration varied from $1.6 \mathrm{mgL}^{-1}$ (TL lake) to $3.1 \mathrm{mgL}^{-1}$ (HK lake). Previous study (Parszuto and Kaliszewska, 2007) demonstrated that the changes in POC are mainly related with primary production, which is confirmed by a positive correlation of POC and Chl-a concentrations. The same conclusion was found in this study that POC in dry season was higher than in wet season in almost lakes (except for TB and BaM lakes), as the same seasonal variation of Chl-a (Fig. 3c).

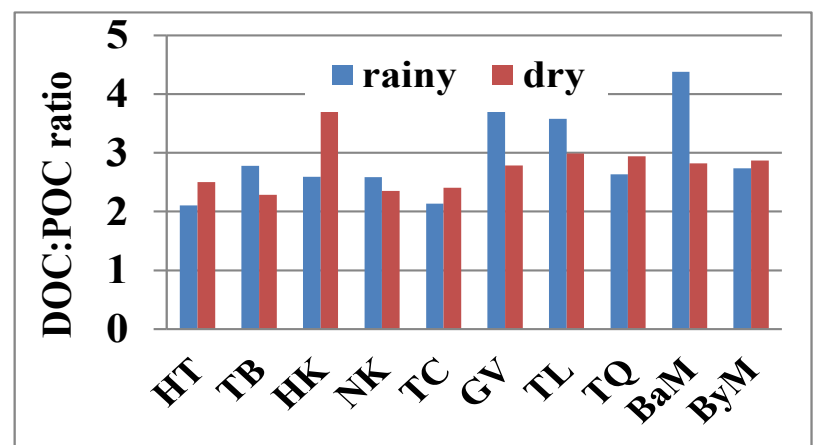

Fig. 4. DOC:POC ratio in rainy and dry season of $\mathbf{1 0}$ lakes in Hanoi

In aquatic ecosystems, the majority of organic carbon is under DOC form, whereas POC typically contributes only $10 \pm 17 \%$ of the total. In this study, DOC:POC ratios of 10 Hanoi lakes varied from 2 to 4 , suggesting DOC dominated organic carbon (Fig. 4).

As known, DOC:POC ratio can vary with season, depth, and trophic state of the lake. This variation depends more on changes in POC concentrations than in DOC ones (Dunalska et al., 2004).

\section{Chemical oxygen demand (COD)}

COD concentrations in 10 lakes in Hanoi fluctuated from $2.0 \mathrm{mgL}^{-1}$ (TQ lake and ByM lake) to very high value of $344 \mathrm{mgL}^{-1}$ (BaM lake). The annual average values of $\mathrm{COD}$ in $\mathrm{HK}$ and $\mathrm{BaM}$ lakes were higher from 2 to 4 times than the permitted value of QCVN 08:2015/BTNMT col. A2 (15 $\left.\mathrm{mgL}^{-1}\right)$ (Tab. 3). High COD values were found in various lakes in the world: Uluabat lake (India): $35.7 \mathrm{mgL}^{-1}$ (Elmaci et al., 2008); Pushkar lake (India): 31.7 - $39.1 \mathrm{mgL}^{-1}$ (Mathur et al., 2008), Gulshan lake (Bangladesh): 49-112 $\mathrm{mgL}^{-1}$ (Karim et al., 2012); Quttina lake (Arab): 37 - $143 \mathrm{mgL}^{-1}$ (Manssour and Al-Mufti, 2010); Taihu lake (China): 49 $\mathrm{mgL}^{-1}$ (Yin et al., 2011).

COD in dry season were higher than in wet season as the same DOC variation, and clearest expression in the BaM lake (Fig. 3d). According to Zhou \& Wang (2010), COD concentration rapidly decreased during the purification phase, but then rapidly increased in the decay phase leading to water quality deterioration.

\subsection{Classification of organic pollution level}

The results of organic pollution levels for 10 lakes observed were given in the table 4 with the as followings: $\mathrm{BaM}>\mathrm{HK}>\mathrm{GV}>\mathrm{NK}>\mathrm{HT}>\mathrm{ByM}>\mathrm{TB}>\mathrm{TQ}>\mathrm{TC}>$ TL.

Within 10 lakes observed, the BaM lake was classified as organic pollution level IV, which was the most heavily contaminated by organic matters where very high values of COD, POC and DOC were observed (Table 3 ). The HK lake showed signs of organic pollution, especially in the dry season (POC: 3.3; DOC: 13.6; COD: $44.3 \mathrm{mgL}^{-1}$ and $\mathrm{Chl}$ a: $\left.9.2 \mu \mathrm{g} \mathrm{L}^{-1}\right)$. Other lakes were organic contamination at level III. (Fig. 3).

Compared with the results from previous studies about the COD concentration in lakes (the TC lake: $32-52$ $\mathrm{mgL}^{-1}$ ); the NK lake (COD: 96-102 $\mathrm{mgL}^{-1}$ ); the GV lake (COD: 134-156 $\mathrm{mgL}^{-1}$ ); the BaM lake (COD: 97-104 $\mathrm{mgL}^{-1}$ ) (Le, 2009), the present COD concentrations of these lakes were lower than before, except the BaM lake has been still highly polluted. This also proves that the lake water quality in the period from March 2014 to February 2015 has been ameliorated thank to the embankment, dredging sludge, application of different water treatment technologies, and preventing untreated wastewater to the lakes (Trinh, 2010).

\section{Conclusions}

Based on the method of Hawke (1962) about the classification of organic pollution level and the monthly observation results of water quality of 10 lakes in Hanoi from March 2014 to February 2015, we found that the BaM were classified as organic pollution level IV, other lakes were organic contamination level III. Organic pollution may come from both allochthonous and autochthonous sources.

Compared with the results from previous studies, the water quality of 10 lakes in the period from March 2014 to February 2015 has been improved, after the applica- 
tion of some positive solutions for lake environmental protection such as lake embankment, dredging sludge, application of different water treatment technologies, preventing untreated wastewater to the lake were taken. (Trinh, 2010). However, they are still organically polluted, especially the BaM lake.

Due to the important role of urban lakes in human lives, it is necessary to regular monitor lake water quality as well as to enhance to apply effective solutions for protection of lake environment.

Acknowledgements: This work was performed the 2014-Quynh-INPC project. The authors thank Institute of Natural Product Chemistry (INPC, VAST) for the financial support.

\section{References}

[1] Afiq WM, WM Khalik and Md.P Abdullah (2012) Seasonal influence on water quality status of Temenggor lake, Perak. The Malaysian Journal of Analytical Sciences, Vol.16, No.2: 163 - 171.

[2] Channar A.G, AM Rind, GM Mastoi, KF Almani, K. H Lashari, M A Qurishi, N Mahar (2014) Comparative study of water quality of Manchhar Lake with drinking water quality standard of world health organization. American Journal of Environmental Protection 3(2), 68-72.

[3] Dunalska J., D. Górniak, M. Teodorowicz, K. Gąsecka (2004) Seasonal Distribution of Dissolved and Particulate Organic Carbon in the Water Column of a Meromictic Lake. Polish Journal of Environmental Studies, Vol.13 (4), 375-379.

[4] Elmaci A, FO Topac, N Ozengin, A Teksoy, S Kurtoglu and HS Baskaya (2008) Evaluation of physical, chemical and microbiological properties of lake Uluabat, Turkey. Journal of Environmental Biology, 29(2), 205-210.

[5] Garnier J, Billen G. and Cugier Ph., (2004) Drainage basin use and nutrient supply by rivers to the coastal zone. A modelling approach to the Seine River. In: Drainage basin nutrient inputs and eutrophication: an integrated approach. P. Wassmann and K. Olli (Eds), 309pp.

[6] Hawke H.A. (1962) River Pollution II. Causes and Effects. Buterworths, London, pp: 311-315.

[7] Karim A., N Akhter and S Hoque (2012) Bacterial status and pollution level in the water of Gulshan lake, Dhaka. Bangladesh J. Zool, 40(2), 165-173.

[8] Kim B, K Choi, C Kim, U-H Lee and Y-H Kim (2000) Effects of the summer monsoon on the dis- tribution and loading of organic carbon in a deep reservoir, lake soyang, Korea. Wat, Res, Vol.34(14), 3495-3504.

[9] Le T.P.Q, Billen, G. Garnier, J. Thery, S. Fezard, C. and Chau, V.M. (2005) Nutrient (N, P) budgets for the Red River basin (Vietnam and China). Global Biogeochem. Cycles, Doi: 10.1029/2004GB002405.

[10] Le Thu Ha (2009) The eutrophication and phytoplankton biodiversity of some lakes in Hanoi, Vietnam. World Lake Conference, Wuhan, China, $391 \mathrm{pg}$.

[11] Manssour K. and Al-Mufti B. (2010) Influence of Industrial, Agricultural and Sewage Water Discharges on Eutrophication of Quttina Lake. Jordan Journal of Civil Engineering, 4(4), 351-366.

[12] Mathur P, S Agarwal and M Nag (2008) Assessment of Physico-Chemical Characteristics and Suggested Restoration Measures for Pushkar Lake, Ajmer Rajasthan (India). Proceedings of Taal 2007: The 12th World Lake Conference: 1518-1529

[13] Meybeck M., Chapman D.V. and Helmer R., 1989. "Global environment monitoring: Global freshwater quality, a first assessment”, Chapter 7: Suspended matter in rivers and lakes, p. 93-104, published by WHO and UNEP.

[14] Mushatq B, R Raina, T Yaseen, A Wanganeo and A. R. Yousuf (2013) Variations in the physicochemical properties of Dal Lake, Srinagar, Kashmir. African Journal of Environmental Science and Technology, Vol.7(7), pp. 624-633.

[15] Parszuto K and E A Kaliszewska (2007) The evaluation of the trophy of selected Olsztyn lakes by means of indices of particulate organic carbon (POC) and dissolved organic carbon (DOC). Limnological Review 7(2), 87-93.

[16] Trinh Thi Thanh. 2010. Water quality of lakes in Hanoi and some precaution for amelioration of water quality. International scientific conference for celebrating 1000 years of Thang Long - Hanoi, city of sustainable development and for peace., 7-9 October 2010, Hanoi, page 1245 - 1252.

[17] Yin Y, Y Zhang, X Liu, G Zhu, B Qin, Z Shi, L Feng (2011) Temporal and spatial variations of chemical oxygen demand in Lake Taihu, China, from 2005 to 2009. Hydrobiologia, 665:129-141.

[18] Zhou XH. \& GX. Wang (2010) Nutrient concentrationvariations during Oenanthe javanica growth and decay in the ecological floating bed system. Journal of Environ-mental Sciences, 22: 1710-1717. 